DOI: 10.1515/prilozi-2015-00ロ

\title{
ISCHAEMIA-DRIVEN OPTIMAL THERAPEUTIC APPROACH IN ASYMPTOMATIC PATIENTS WITH HIGH CARDIOVASCULAR RISK: THE VALUE OF CLINICAL, LABORATORY AND MYOCARDIAL SPECT IMAGING FINDINGS
}

\section{Irena Peovska Mitevska, Jelka Davceva Pavlovska, Elizabeta Srbinovska, Marijan Bosevski, Maja Zdravkovska, Daniela Pop Gorceva, Marina Zdravevska}

University Cardiology Clinic, Institute for Pathophysiology and Nuclear Medicine, Ss. Cyril and Methodius University, Skopje, R. Macedonia

Corresponding Author: Peovska I, University Cardiology Clinic, Medical Faculty, 1000 Skopje, R. Macedonia, Tel: + 389 (0) 722310 46; (0)2 31131 16; E-mail: peovskai@yahoo.com

\begin{abstract}
Background: We wanted to evaluate the presense of myocardial ischaemia in asymptomatic patients with high cardiovascular risk, the influencing clinical and laboratory factors and the impact of ischaemia on final management decision.

Material and methods: We evaluated 60 asymptomatic patients with high CV risk, who underwent SPECT myocardial perfusion imaging (MPI) for detection of suspected CAD. We used the 17 segment model for quantitative and semiquantitative scan perfusion and function analysis using perfusion scores. All patients had full blood laboratory analyses including lipid values, presence of albuminuria, rest and stress ECG. Logistic regression analysis was used to assess the impact of clinical and laboratory parameters on myocardial ischaemia prevalence.

Results: Stress-inducible ischaemia was found in 19 pts (33\%), fixed defects were found in $13 \%$ and mixed defects in $9 \%$ of cases. The average ischaemia amount was $10 \%$. Mild ischaemia was found in 12 patients $(64 \%) \pm$ summed stress score (SDS) $<4$, moderate ischaemia in 5 patients $(26 \%) \pm$ SDS $5 \pm 7$ and severely abnormal scans in 2 patients $(10 \%) \pm$ SDS $>7$. Severe ischaemia was only related to the duration of diabetes. Six pts with severe ischaemia had ST depression $>2 \mathrm{~mm}$ on stress study, and a higher wall motion index and LVEF fall > 5\% during stress study $(\mathrm{p}<0.01)$. Stepwise logistic regression analysis for prediction of stress-induced ischaemia showed OR 2.4 (95\% CI 1.7í 3.6) for stress-induced ECG changes and OR 3.9 for presence of DM over 10y (95\% CI 2.3í 6.6). Seven patients with ischaemia $>10 \%$, were referred for coronary angiography.

Conclusions: MPI is a valuable method for preclinical assessment of myocardial ischaemia in patients with high CV risk, which can improve prognosis and guide treatment decision.
\end{abstract}

Key words: myocardial imaging, ischaemia, management decision.

\section{Introduction}

Coronary artery disease (CAD) is the leading cause of morbidity, mortality, and cost of management of asymptomatic high risk patients. Acute myocardial infarction or sudden cardiac death might be the first clinical presentation in asymptomatic patients due to insufficient screening and proper management of CAD. The prevalence of silent ischaemia in diabetic patients is between 22 and $51 \%$. Cardiovascular disease is the cause of death in $65 \pm$ $70 \%$ of persons with diabetes. Diabetes is considered as CAD equivalent and diabetic patients have more extensive atherosclerosis with a higher prevalence of multi-vessel coronary artery disease (CAD), frequent silent myocardial ischaaemia, and infarction with a higher cardiac event rate when compared with non-diabe- 
tic patients. Although there has been a significant decline in mortality because of CAD in the overall population in the past three decades, reduction of CAD mortality in diabetic patients has proved exceptionally difficult. Non-diabetic men have experienced a $36 \%$ decline in cardiovascular mortality, compared with a $13 \%$ decline for diabetic men. Similarly, cardiovascular mortality has decreased by $27 \%$ in nondiabetic women but increased by $23 \%$ in diabetic women. Proposed strategies that may favourably affect CAD risk and outcomes in the high risk asymptomatic population include identifying patients with subclinical disease at high risk of future cardiac events. Such subjects are likely to be good candidates for aggressive risk factor management. Current risk score models (SCORE, FRAMINGHAM, PROCAM) show inferiority for individual risk stratification and ability to predict the presence of ischaemia. Proposed strategies that may favourably affect CAD risk and outcomes in this population include identifying individuals with subclinical disease at high risk of future cardiac events. The dilemma of the best diagnostic approach to asymptomatic patients with high $\mathrm{CV}$ risk in relation to the optimal therapeutic approach is still ongoing. Controversy arises regarding whether imaging-based risk stratification improves the patient's management and prognosis compared to the traditional risk factor based stratification.

\section{Materials and methods \\ Study Population}

Sixty consecutive asymptomatic patients (36 male, 24 female; age range $63 \pm 15$ years), with high cardiovascular (CV) risk based on the European Society of Cardiology SCORE risk stratification system (> 5\% risk for fatal cardiovascular event in the next 10 years) without previously known or established CAD were included in the study. All patients completed the WHO Rose Angina Questionnaire for confirmation of the asymptomatic status.

Physical examination of pts was carried out regarding their blood pressure, weight, height, waist and body mass index (BMI). Arterial hypertension (HTA) was defined as an ambulatory systolic blood pressure $>/=140 \mathrm{mmHg}$, or/and diastolic pressure $>/=90 \mathrm{mmHg}$, or as antihypertensive drugs used. Weight was presented in kilograms $(\mathrm{kg})$ and body mass index (BMI) in $\mathrm{kg} / \mathrm{m}^{2}$. According to the European Society of Cardiology criteria: hypertri- glyceridaemia was defined as a value of triglycerides $>/=1.7 \mathrm{mmol} / \mathrm{L}$ and a low $\mathrm{HDL}$ as a value of $<1.03 \mathrm{mmol} / \mathrm{L}$, hyperpipidaemia as LDL > 2.5 $\mathrm{mmol} / \mathrm{L}$ for high risk patients. Obesity was defined as BMI $>30 \mathrm{~kg} / \mathrm{m}^{2}$ and increased weight as BMI > 25 and $<29.9 \mathrm{~kg} / \mathrm{m}^{2}$. Waist circumferences $>88 \mathrm{~cm}$ in women and $>102 \mathrm{~cm}$ in men was defined as abdominal obesity according to ATP panel III criteria. Patients' risk factors were analysed (hypertension, dyslipidaemia, diabetes mellitus type 2, peripheral artery disease, obesity, smoking, family history of CAD). Full blood laboratory analyses with lipid status (total lipids, cholesterol, LDL, HDL, Triglycerides), fasting glucose levels, $\mathrm{HbA1C}$ in diabetic patients, blood urea and creatinin levels as well as albuminuria (30-300 mg/l) for patients with diabetes and hypertension was performed. Clinical and laboratory characteristics are shown in Tables 1 and 2. Left ventricular diastolic as well as global and regional systolic function was assessed in all patients by transthoracic 2D echocardiography using Bi-plane Simpson's rule. All patients had preserved LV rest systolic function with left ventricular ejection fraction (LVEF > 55\%). Rest ECG was performed in all patients and sinus rhythm at rest was one of the inclusion criteria. Pathological Q waves, ST segment abnormalities and signs of left ventricular hypertrophy were assessed in all patients.

Exclusion criteria: typical stable angina pectoris, previously known or established CAD (history of myocardial infarction, acute coronary syndromes, previous percutaneous intervention or coronary artery bypass surgery), LVEF $<55 \%$ at rest, severe valvular disease, atrial fibrillation, presence of pace-maker, severe chronic pulmonary disease.

\section{Study protocol}

All patients with established inclusion criteria underwent laboratory analyses, rest ECG and rest transthoracic echocardiography for assessment of regional and global LV function and myocardial perfusion Single Photon Emission Computed Tomography (SPECT) imaging for detection of silent myocardial ischaemia, silent myocardial infarction and global and regional LV performances. (MPI).

Myocardial perfusion SPECT imaging

MPI SPECT imaging was performed using one day rest stress protocol with radiotracer Tc-99m sestamibi, using $15 \mathrm{mCI}$ for the rest and $25 \mathrm{mCI}$ for the stress study. We used a single head Siemens e-cam gamma camera. 42 patients $(70 \%)$ underwent treadmill stress testing with the Bruce protocol and 17 patients (30\%) had a Dipiridamole test. Blood pressure, 
heart rate, ECG changes at rest and during stress, as well as physical exercise obtained in METs (metabolic equivalent) were analysed. We used the 17 segment model for quantitative Bull's eye analysis of regional myocardial perfusion and function. Myocardial perfusion was assessed using a 5 point score system $(0-$ normal radiotracer uptake; 1 - mild, 2 - moderate; 3 - severe hypoperfusion; 4 - absent uptake) Semiquantitative analysis of regional perfusion at rest and under stress was performed using summed stress score (SSS), summed rest score (SRS) and summed differential score (SDS), aimed to assess the presence and extent of myocardial ischaemia. Scan abnormalities were defined as follows: SSS < 4 normal perfusion; 4-8 mild; 9-13 moderate; > 13 severely abnormal scan. SDS $<6$ mild $(<10 \%$ of LV); SDS 7-10 moderate $(10-15 \%$ of LV); SDS > 10 severe ischaemia (> 15\% of LV). LV volumes, LVEF at rest and stress, presence of transit ischemic LV dilation (TID) defined as abnormal if $>1,2$, visualization of right ventricle and lung uptake were also analysed. Regional wall motion analysis was assessed using a 6 point scoring system at rest and under stress $(0-$ normal wall motion, $1-$ mild, 2 - moderate; 3 - sereve hypokinesia, 4 - akinesia, 5 - dyskinesia) using the wall motion score index (total wall motion score divided by 17).

\section{Coronary angiography}

All patients with at least moderate myocardial ischaemia (SDS > 7- > 10\% of myocardium) underwent coronary angiography based on the latest European Society of Cardiology (ESC) guidelines for treatment of stable coronary artery disease and myocardial revascularization. Presence, localization, severity of coronary stenosis and number of vessels involved were analysed using Syntax Score. Percutaneous coronary intervention with stenting or coronary artery bypass surgery was performed according to the latest myocardial ESC revascularization guidelines.

\section{Medical therapy and life style advices}

Medical therapy was reviewed and all patients were put on optimal medical treatment based on the latest ESC guidelines for CV prevention and management of stable CAD. Lifestyle advice was given to all included patients.

The study was conducted according to the Helsinki Declaration for Clinical Studies.

\section{Statistical analysis}

We used the SPSS statistical package (version 18.0). Categorical values were expressed in percents, continued as mean value $\pm \mathrm{SD}$. We used the Pearson method for correlations assessment. Multivariable regression analysis was built to identify factors associated independently with the presence of silent myocardial ischaemia. $\mathrm{P}<0.05$ was found as statistically significant for all statistical tests.

\section{Results}

A high prevalence of metabolic risk factors was found in the evaluated population (Tables 1 and 2). Arterial hypertension and dyslipidaemia were found in $64 \%$ and $48 \%$ of patients. Obesity was found in $39 \%$, and increased weight in $43.3 \%$ of the patients. Hypertriglyceridaemia was found in $42 \%$, and low HDL cholesterol in $25.6 \%$ of patients. The population had a mean diabetes duration of 6.5 years and the mean value of glycaemia was $8.75 \pm 2.50$ $\mathrm{mmol} / \mathrm{L}$. Higher mean values of systolic, diastolic blood pressure, BMI, plasma cholesterol, LDL-cholesterol and triglycerides were found.

Table 1

Basic characteristics of the study population

\begin{tabular}{|l|c|}
\hline Variables & No of patients (\%) \\
\hline Age & $63 \pm 15$ \\
\hline Gender & $36 \mathrm{~m} ; 24 \mathrm{f}$ \\
\hline DM & $24(40 \%)$ \\
\hline HTA & $38(64 \%)$ \\
\hline HLP & $28(48 \%)$ \\
\hline Obesity & $23(39 \%)$ \\
\hline PAD & $7(12 \%)$ \\
\hline HbA1C \% in DM & $7.9 \pm 7.2$ \\
\hline EF $(\%)$ & $58 \pm 6 \%$ \\
\hline Microalbuminuria & $27(45 \%)$ \\
\hline
\end{tabular}

Table 2

Clinical characteristics of the study population

\begin{tabular}{|l|c|}
\hline Variables & Values \\
\hline $\begin{array}{l}\text { Macroalbuminuria } \\
(>300 \mathrm{mg} / \mathrm{l})\end{array}$ & $3(5 \%)$ \\
\hline ACE/ARB & $60(100 \%)$ \\
\hline Beta blocker & $45(75 \%)$ \\
\hline Statins & $49(82 \%)$ \\
\hline Aspirin & $60(100 \%)$ \\
\hline Active smoker & $15(25 \%)$ \\
\hline HDL (mmol/l) & $0.9 \pm 0.4$ \\
\hline LDL (mmol/l) & $3.2 \pm 0.4$ \\
\hline TGL (mmol/l) & $2.3 \pm 0.6$ \\
\hline Mean RF per pt & $2 \pm 1$ \\
\hline
\end{tabular}


$100 \%$ of patients received Aspirin, and $82.1 \%$ of them statins. Almost $38.5 \%$ were on insulin therapy, and $61.5 \%$ on oral antidiabetic therapy. All patients received ACE inhibitors and $75 \%$ were on beta blocker therapy.

\section{Myocardial SPECT findings}

Stress-inducible ischaemia was found in 19 pts $(33 \%)$, of whom 8 pts $(40 \%)$ were diabetic. Fixed defects were found in $13 \%$ and mixed defects in $9 \%$ of cases. The average percentage of ischaemia was $10 \%$. Mildly abnormal scans were found in 7 patients $(36 \%)$ - summed stress score (SSS) $<8$, moderate abnormality in 4 patients $(22 \%)-$ SSS $<13$ and severely abnormal scans in 8 patients (42\%) - SSS $>13$. Severe ischaemia was only related to the duration of diabetes.

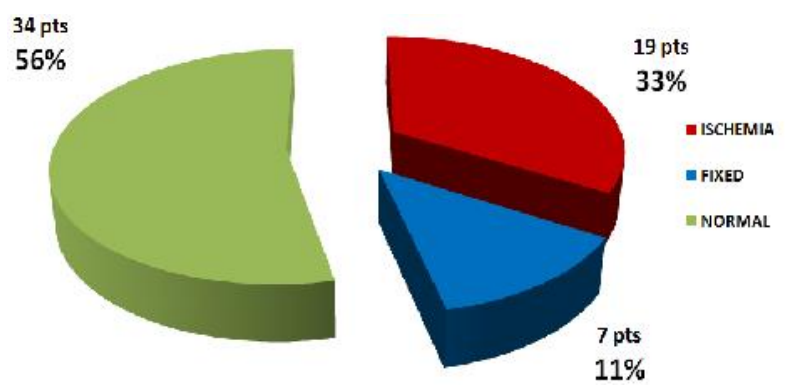

Figure 1 - Patients with abnormal scintigraphic findings

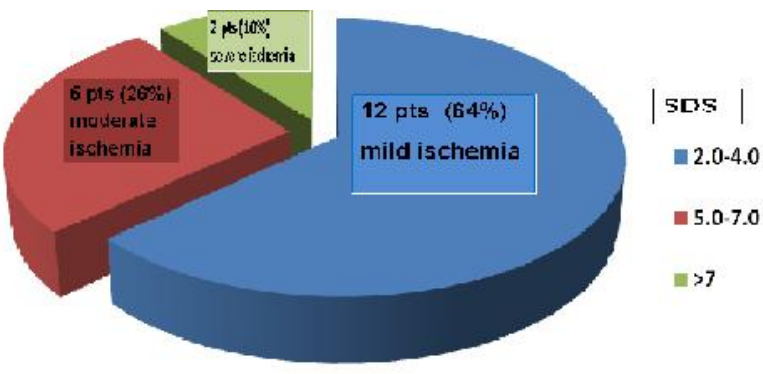

Figure 2 - Severity of ischaemia in study population

Table 3

ECG and haemodynamic findings in patients with normal SPECT study

\begin{tabular}{lccc}
\hline \multicolumn{1}{c}{ Variables } & Ischemia $\mathbf{n}=\mathbf{1 9}$ & $\begin{array}{c}\text { Normal study } \\
\mathbf{n = 3 4}\end{array}$ & p-value \\
\hline ST segment depression & $11 / 19(575)$ & $0 / 3$ & $<0.01$ \\
No increase in BP of BP fall & $5 / 19(26 \%)$ & $3 / 34(8.8 \%)$ & $<0.01$ \\
$>$ 10 mmHg & $12 / 19(64 \%)$ & $6 / 34(18 \%)$ & $<0.01$ \\
Dypiridamol & $7 / 19(36 \%)$ & $28 / 34(82 \%)$ & $<0.01$ \\
Treadmill stress test & $7 \pm 1$ & $8 \pm 2$ & NS \\
METs & & & \\
\hline
\end{tabular}

Table 4

Scintigraphic findings in patients with ischemia and fixed defects

\begin{tabular}{lccc}
\hline \multicolumn{1}{c}{ Variables } & Ischemia n = 19 & Fixed defects n= 7 & p-value \\
\hline WMI & $1,3 \pm 0,4$ & $1.8 \pm 0.5$ & $<0.05$ \\
TID & $5 / 19(26 \%)$ & $0 / 7$ & $<0.001$ \\
EF fall $>\mathbf{5 \%}$ & $4 / 19(21 \%)$ & $1 / 7(14 \%)$ & $<0.01$ \\
Increased lung uptake & $3 / 19(15 \%)$ & $2 / 7(28 \%)$ & $<0.001$ \\
\hline
\end{tabular}

Table 5

Stepwise logistic regression analysis for predictors of stress induced ischemia

\begin{tabular}{lcccccccc}
\hline & B & S.E. & Wald & df & Sign & OR & 95\% & CI \\
\hline DM > 10y & 1.965 & 0.321 & 5.360 & 1 & 0.000 & 3.932 & 2.398 & 6.147 \\
$\begin{array}{l}\text { ECG ST } \\
\text { depression }\end{array}$ & 1.032 & 0.523 & 6.579 & 1 & 0.000 & 2.446 & 1.734 & 3.567 \\
EF fall > 5\% & 1.367 & 1.497 & 7.323 & 1 & 0.003 & 2.367 & 1.256 & 3.468 \\
\hline
\end{tabular}

Six pts with severe ischaemia (75\%), had ST segment depression $>2 \mathrm{~mm}$ on pharmaceutical stress, and a higher wall motion index $(\mathrm{p}<$ 0.01). Pts with severe ischaemia had a fall of LVEF during stress > 5\% compared to rest
LVEF. Transit ischaemic dilatation (TID) was observed in 5 pts with severe ischaemia. Stepwise logistic regression analysis of stress-induced ischaemia showed OR 2.4 (95\% CI 1.7-3.5) for stress induced ECG changes, OR 3.9 for 
presence of DM over 10 y (95\% CI 2.3-6.1) and $\mathrm{OR}$ of 2.3 for EF fall $>5 \%$ during stress study (95\% CI 1.2-3.4). 7 pts with ischaemia > $10 \%$ were referred for coronary angiography. Two pts had PCI to RCA, 4 pts had PCI to LAD and 1 patient had PCI to LAD and LCx. Pts with mild ischaemia (SSS $<8$ ) and normal MPI findings were put on intensive medical therapy and advice for life-style modification. We found no correlation of traditional risk factors and albuminuria with the presence of myocardial ischaemia ( $r-0.44$ and $r-0.39$ respectively).

\section{Discussion}

Previous studies have shown a significant correlation with the increasing number of risk factors and the presence of coronary artery disease in asymptomatic patients, especially in the type 2 diabetic population [1,2]. Our study showed diabetes duration, ST segment depression and fall in EF during the stress study as predictors of silent myocardial ischaemia. The important question is: should we screen asymptomatic patients, who to screen and how to screen? There is enough evidence of cost effectiveness of CAD screening and we also have guidelines on how to approach it. Screening for silent coronary artery disease in high $\mathrm{CV}$ risk patients is aimed to detect the disease in an early stage in order to initiate early appropriate treatment, having in mind that in up to $60 \%$ of male and $42 \%$ of female patients the first initial presentation of CAD is acute myocardial infarction and in around 40\% sudden cardiac death [2]. Rupture or erosion of vulnerable but haemodynamically insignificant plaque underlies $70 \%$ of acute coronary syndromes. Consequently, there is a strong argument for using atherosclerosis imaging to evaluate the risk of incident CAD [3]. The prevalence of myocardial perfusion abnormalities is the same in diabetic patients without known CAD and non-diabetic patients with known CAD [3). The diagnostic and prognostic value of functional imaging of CAD with MPI SPECT is well established. Moreover, a meta-analysis involving patients with normal MPI SPECT demonstrated that the median annual rate of cardiac death or nonfatal myocardial infarction is much smaller in non-diabetic patients $(0.6 \%)$ than in diabetic populations, in whom published rates have ranged from 1.6 to $3.3 \%$ [6]. This highly variable prevalence, together with the fact that a normal MPI SPECT is associated with a greater cardiovascular risk in diabetic patients, points to the need for additional clinical or imaging data to select the patients who will actually benefit from a screening procedure for occult CAD [7, 8]. The European and American guidelines recommend screening asymptomatic high-risk patients, which includes diabetic patients with evidence of peripheral or carotid occlusive arterial disease, microvascular disease (proliferative retinopathy, nephropathy), or at least two cardiovascular risk factors (diabetic dyslipidaemia, hypertension, smoking, family history of premature CAD) [4, 9]. Recommended risk strafication models (SCORE, FRAMINGHAM, PROCAM), have evident inferiorities, which does not include many additional risk factors, diabetes, family history, obesity and leaves many patients with residual risk. These models do not predict the presence of myocardial ischaemia which has a prognostic information.

Although the emerging evidence supports the appropriateness of testing patients with vascular disease, recent studies have reported a similar frequency of abnormal MPI SPECT studies in asymptomatic diabetic patients with and without two or more cardiovascular risk factors [10]. In pooled studies including both diabetic and non-diabetic patients and symptomatic as well as asymptomatic patients, an unequivocally normal stress MPI has been associated with a cardiac event rate of $<1 \%$ per year. With abnormal stress MPI studies, the extent and severity of myocardial ischaemia strongly predicts short and long-term risks of coronary events. At least eight subsequent studies have confirmed that event rates vary with the size of perfusion defect [10]. Kang et al. showed that hard cardiac event rates in diabetics with mild, moderate, and severe perfusion defects were $1-2$, 3-4, and 7\% per year, respectively [11]. Giri et $a l$. also showed that despite the higher rates of revascularization, diabetic patients had an almost two-fold increase in the hard cardiac event rate $(8.6 \%)$ when compared with non-diabetics (4.5\%) [12]. De Lorenzo et al. showed that an abnormal MPI significantly increased the annual incidence of hard cardiovascular events 
(9\%) when compared with a normal MPI (2\%). Furthermore, in this study, established risk factors were related neither to the extent of abnormalities on MPI nor to cardiovascular events [13]. In a subsequent larger study comprising 1737 patients, Zellweger et al. [43] showed that frequency of abnormal MPI (39\%) and annual critical event rate in asymptomatic diabetics were comparable to those of diabetic patients with angina (44\%) [14]. Similarly, Miller et al. studied 27165 patients, of whom 4736 were diabetic, and found that the prevalence of an abnormal MPS was the same in asymptomatic and symptomatic diabetic patients (58.6 vs. 59.5\%); this was significantly higher than in asymptomatic non-diabetic (46.2\%) and symptomatic non-diabetic (44.4\%) patients. A subsequent follow-up study confirmed an increased prevalence of severe angiographic CAD and mortality in those diabetic patients with severe asymptomatic ischaaemia [15]. The only large prospectively designed study of asymptomatic ischaemia in unselected type 2 diabetics (DIAD) with no prior CAD, found $22 \%$ prevalence of an abnormal MPI study, with marked perfusion abnormalities occurring in $6 \%$ of patients. This study also demonstrated that traditional cardiovascular risk factors and novel biomarkers (hs-C-reactive protein, homocysteine, lipid subfractions, and plasminogen activator inhibitor-1) were not of abnormal myocardial perfusion. In comparison, male gender, duration of diabetes, and the presence of cardiac autonomic dysfunction were strong predictors of ischaemia [5]. The DIAD 2 trial confirmed that myocardial ischaemia can be reduced by intensive medical treatment and risk factors control. The Nuclear SPECT imaging subgroup of the COURAGE Trial showed that the most significant prognostic parameter was an ischaemia decrease of $>5 \%$ in the follow-up period irrespective of the treatment mode [16].

Our study showed the presence of silent ischaemia in $33 \%$ of the evaluated high risk patients, which is similar to the percentage referred to in the literature. The differences in the prevalence of silent ischaemia might be due to the differences in the evaluated population, diabetes duration and control, risk factors control in the different parts of the world, stress methodology, imaging techniques and interpre- tive definitions. There has been a long debate concerning the best screening approach in asymptomatic patients with high CV risk. European guidelines on $\mathrm{CV}$ prevention and treatment of stable CAD as well as American guidelines on screening for CAD in asymptomatic adults indicates that imaging of atherosclerosis and functional imaging of CAD have a place and might be used in this population. It is important to know the predictors of myocardial ischaemia in high risk population in order to properly select patients for noninvasive functional imaging [9]. Clinical outcome in patients with moderate and severe ischaemia might be considerably improved by myocardial revascularization and aggressive therapy at an early stage. Hopefully, prospective follow-up of our patients will extend our knowledge and clinical approach in asymptomatic high-risk patients.

\section{Conclusion}

The presence of silent myocardial ischaemia in high-risk asymptomatic patients is high, especially in patients with long-standing diabetes. SPECT MPI is a valuable method for preclinical assessment of myocardial ischaemia in patients with high CV risk. MPI can improve cardiac risk stratification and guide management decisions in this group of patients. Intensified risk factor control and coronary revascularization in patients with minimum moderate ischaemia could modify the natural history of the disease and improve prognosis.

\section{REFERENCES}

1. Fuster V, Mearns BM. The CVD paradox: mortality vs prevalence. Nat Rev Cardiol. 2009; 6: 669.

2. Shah PK. Screening asymptomatic subjects for subclinical atherosclerosis: can we, does it matter, and should we? J Am Coll Cardiol. 2010; 56: 98-105.

3. Henrik Sillesen, Erling Falk, Rigshospitalet, et al. Why not screen for subclinical atherosclerosis? The Lancet. 2011; 03: 28; 759-762.

4. Greenland P, Alpert JS, Beller GA, et al. 2010 ACCF/AHA guideline for assessment of cardiovascular risk in asymptomatic adults: a report of the American College of Cardiology Foundation/American Heart Association Task Force on Practice Guidelines. J Am Coll Cardiol. 2010; 56: e50-103.

5. Wackers FJ, Young LH, Inzucchi SE, et al. Detection of silent myocardial ischemia in asymptomatic diabetic subjects: the DIAD study. Diabetes Care. 2004; 27: 1954-1961. 
6. Carli MF, Hachamovitch R. Should we screen for occult coronary artery disease among asymptomatic patients with diabetes? J Am Coll Cardiol. 2005; 45 : 50-53.

7. Rajagopalan N, Miller TD, Hodge DO, Frye RL, Gibbons RJ. Identifying high-risk asymptomatic diabetic patients who are candidates for screening stress single-photon emission computed tomography imaging. J Am Coll Cardiol. 2005; 45: 43-49.

8. Bax JJ, Bonow RO, Tschöepe D, Insucchi SE, Barrett EJ. Early detection of coronary heart disease in diabetic patients without symptoms of coronary artery disease: implications for expanded use of myocardial perfusion imaging. Br J Diabetes Vasc Dis. 2005; 5: 283-288.

9. European Guidelines on cardiovascular disease prevention in clinical practice (version 2012) The Fifth Joint Task Force of the European Society of Cardiology and Other Societies on Cardiovascular Disease Prevention in Clinical Practice. European Heart Journal. (2012) 33, 1635-1701.

10. Shaw LJ, Iskandrian AE. Prognostic value of gated myocardial perfusion SPECT. J Nucl Cardiol. 2004; 11: 171-185.

Резиме

\section{SPECT-}

\begin{tabular}{|c|c|c|c|c|c|c|}
\hline рен & ОВСК & & гвск, & елк & & Вчев \\
\hline & J & бет & рбо & & & риј \\
\hline $\begin{array}{l}\text { ше ескки, } \\
\text { рчев }\end{array}$ & $\begin{array}{c}\mathbf{j} \\
\text { pин }\end{array}$ & $\begin{array}{l}\text { др } \\
\text { др }\end{array}$ & $\begin{array}{l}\text { вКовск } \\
\text { вевск }\end{array}$ & , & ниел & \\
\hline
\end{tabular}

Универзитетска клиника за кардиологија, Институт за патофизиологија и нуклеарна медицина, Универзитет „Св. Кирил и Методиј“, Скопје, Р. Македонија

ели: Евалуација на присуство на миокардна исхемија кај асимтпоматски пациенти со висок кардиоваскуларен ризик, влијание на клиничките и лабораториски фактори и улогата на исхемијата врз финалната тераписка одлука.

11. Kang X, Berman DS, Lewin H, et al. Comparative ability of myocardial perfusion single-photon emis
11. Kang X, Berman DS, Lewin H, et al. Comparative ability of myocardial perfusion single-photon emission computed tomography to detect coronary artery disease in patients with and without diabetes mellitus. Am Heart J. 1999; 137: 949- 957.

12. Giri S, Shaw LJ, Murthy DR, Travin MI, Miller DD, Hachamovitch R, Borges-Neto S.

13. De Lorenzo A, Lima RS, Siqueira-Fiho AG, Pantoja MR. Prevalence and prognostic value of perfusion defects detected by stress technetium-99m sestamibi myocardial perfusion single-photon emission computed tomography in asymptomatic patients with diabetes mellitus and no known coronary artery disease. Am J Cardiol. 2002; 90: 827-832.

14. Zellweger MJ, Hachamovitch R, Kang X, et al. Prognostic relevance of symptoms versus objective evidence of coronary artery disease in diabetic patients. Eur Heart J. 2004; 25: 543- 550.

15. Miller TD, Rajagopalan N, Hodge DO, Frye RL, Gibbons RJ (2004) Yield of stress single-photon emission computed tomography in asymptomatic patients with diabetes. Am Heart J. 147: 890-896.

16. Jamieson M. Bourque, MD, MHS; George A. Beller. Stress Myocardial Perfusion Imaging for Assessing Prognosis: An Update. J Am Coll Cardiol Img. 2011; 4(12): 1305-1319.

териј л и методи: Евалуирани се 60 асимптоматски пациенти со висок кардиоваскуларен ризик, кај кои е направена миокардна перфузиона сцинтиграфија (МПC) SPECT во мирување и оптоварување заради детекција на суспектна коронарна артериска болест. Користен е 17-сегментен модел за квантитативна и семиквантитативна анализа на миокардната перфузија и функција од SPECT скеновите со користење перфузиони скорови. Кај сите пациенти е направена комплетна лабораториска анализа, липиден статус, албуминирија, ЕКГ во мирување и при оптоварување. Користена е логистичка регресиона анализа за процена на влијанието на клиничките, лабораториските и хемодинамските параметри при оптоварување врз присуство на миокардна исхемија.

езулт ти: Стрес индуцирана исхемија е најдена кај 19 пациенти (33\%), фиксни дефекти кај $13 \%$ и мешан тип дефекти кај $9 \%$ од пациентите. Просечната големина на исхемијата изнесуваше $10 \%$. Лесна исхемија е најдена кај 12 пациенти (64\%) - сумиран диференцијален скор (СДС) $<4$, умерена исхемија кај петмина пациенти (26\%) - СДС 5-7 и тешка исхемија кај двајца пациенти (10\%) - СДС > 7. Тешката исхемија корелираше само со траењето на диајбетесот. Шестмина пациенти со тешка исхемија имаа СТсегмент депресија > 2 мм при оптоварувањето, повисок индекс на зидна ки- 
нетика и пад на ЛВЕФ > 5\% при студијата на оптоварување (р < 0.01). Логистичката регресиона анализа за предикција на стрес индуцирана исхемија покажа OR 2.4 (95\% CI 1.7-3.6) за стрес индуцирани ЕКГ-промени и OR 3.9 за присуство на дијабетес над 10 години (95\% CI 2.3-6.6). Седуммина пациенти со исхемија > 10\% беа упатени на инвазивно иследување. клучоци: Миокардната перфузиона сцинтиграфија е корисен и докажан метод за претклиничка евалуација на миокардна исхемија кај пациенти со висок кардиоваскуларен ризик, што може да ја подобри прогнозата и финалната тераписка одлука.

лучни зборови: миокардна визуализација, исхемија, тераписка одлука. 